\title{
A ğ Dışsallıkları: Türkiye Mobil İletişim Piyasası İçin Ampirik Bir Analiz
}

\author{
Network Externalities: An Empirical Analysis For The Turkish Mobile \\ Communications Market
}

\author{
Mikail KAR, Bursa Uludağ Üniversitesi, Türkiye, mklkar@gmail.com \\ Orcid No: 0000-0002-4036-7355
}

\begin{abstract}
Öz: Bu çalışmada Türkiye Mobil Telekomünikasyon Piyasası'ndaki ağ dışsallıklarının varlığı ve etkileri analiz edilmektedir. Ampirik analizde piyasa talebini ve piyasa fiyatın dikkate alan dört farklı model Türkiye'deki mobil operatörlere ait 2005q1-2019q1 dönemleri arasindaki panel veriler kullanılarak dinamik ortak korelasyonlu etkiler (DCCE) tahmincisi yardımıyla tahmin edilmiştir. Elde edilen sonuçlar talep ve fiyatların belirlenmesinde ă̆ dlssallıklarının etkili olduğunu göstermektedir. Sonuçlara göre geçmis dönemdeki ağa katılma talebinde \%1'lik bir artıs mevcut dönemdeki ă̆a katılma talebini yaklaşı \%0.3 artıırken, piyasa fiyatın yaklaş̧ı \%2 artırmaktadır. Geçmiş dönemdeki ağı kullanma talebinde meydana gelecek \%1 'lik bir artış mevcut dönemdeki ağı kullanma talebini \%0.7 artırırken piyasa fiyatını yaklaşık \%1.1 artırmaktadır. Ayrıca geçmiş dönemdeki piyasa yoğunlaşmasında meydana gelecek \%1 lik bir artıșın mobil iletișim talebini \%0.1 ile \%0.7 arasında, piyasa fiyatın ise \%2.5 ile \%3 arasında artıracağ̀ tespit edilmiştir.
\end{abstract}

\section{Anahtar Sözcükler: Ağ Dışsallıkları, Mobil Telekomünikasyon Piyasası, Mobil İletişim Talebi, DCCE Tahmincisi} JEL Siniflandırmast: D62, D85, D4, D22, C13

\begin{abstract}
In this study, the existence and effects of network externalities in Turkish Mobile Telecommunications Market is analyzed. In empirical analysis, four different models, both taking market demand and market price into account, were estimated using panel data from the 2005q1-2019q1 periods of mobile operators in Turkey with the help of dynamic common correlated effects (DCCE) estimator. The results show that network externalities are effective in determining demand and prices. According to the results, a 1\% increase in the demand for joining the network in the past period increases the demand for joining the network in the current period by about $0.3 \%$, while increases the market price by about $2 \%$. A $1 \%$ increase in the demand to use the network in the past period increases the demand to use the network in the current period by $0.7 \%$, increases the market price by about $1.1 \%$. Furthermore, it was determined that a $1 \%$ increase in market concentration in the past period would increase the demand for mobile communication between $0.1 \%$ and $0.7 \%$ and increase the market price between $2.5 \%$ and $3 \%$.
\end{abstract}

\section{Keywords: Network Externalities, Mobile Telecommunications Market, Demand For Mobile Communications, DCCE Estimator} JEL Classification: D62, D85, D4, D22, C13

\section{Giriş}

A ̆g endüstrilerindeki mal ve hizmetlerin genel olarak tek başlarına kullanıldığında çok az değeri vardır veya hiç bir değeri yoktur. Değerlerinin büyük kısmı başka tüketicilerinde o ürünü kullanmasından ve/veya başka ürün ve hizmetlerle birleştirilerek kullanılmasından gelir. Yani bu piyasalarda tüketiciler faydanın büyük kısmını ürün ya da hizmetin kendisinden değil, bu ürünleri çevreleyen ağlardan elde ederler (Frels, Shervani ve Srivastava, 2003:29). İşte tüketicilerin ilgili ürün ya da hizmetten kazandığı faydanın, diğer kullanıcıların ve tamamlayıcı malların varlığından etkilenmesi olarak ifade edilebilecek ă̆ dışsallıkları bu piyasaların analizlerinde ön plana çıkan konulardan biridir. Dışsallıklar konusunun ekonomik literatürde geçmişi Marshall ve Pigou'ya kadar dayanmasına rağmen ağ dişsallıkları, dışsallık konusunun ağ endüstrilerinde ortaya çıkan ve nispeten daha yeni ve özel bir türü olarak ifade edilebilir. Ağ dışsallıklarının nedeni, hali hazırdaki tabanın mevcut ve potansiyel tüketicilere belirsizlik, uyumluluk ve teknik özellikler gibi konularda bilgiler aktarması ve tamamlayıcıların sayısının, çeşitliliğinin ve kalitesinin artması şeklinde avantajlar sunmasıdır (Farrell ve Klemperer 2007: 2009). Aslında bu durum bu piyasaların ağ endüstrileri olarak adlandırılmasının altında yatan en temel nedendir (Shankar ve Bayus 2003:376; Mclntyre ve Subramaniam, 2009:1495; Katz ve Shapiro, 1985:424; Arthur, 1996:101).

Mobil telekomünikasyon piyasaları son yirmi yılın ön plana çıkan ağ endüstrilerinden biri olarak dikkat çekmektedir. Mobil telekomünikasyon, iletişimdeki sınırları kaldırma ve daha çok insanı birbirine bağlama çabası itibari ile ă̆ dışsallıklarının görüldüğü en doğal piyasa örneklerindendir. Ağın mevcut boyutunu gösteren toplam abone sayısı ve hizmetin kullanımını gösteren aylık ortalama kullanım miktarı mevcut ve potansiyel tüketicilerin abone olma isteğini, kullanım miktarını ve ödeme istekliliğini etkiler. Yani ağa katılma ve ağı kullanma talebi (Kar, 2019) mevcut ve potansiyel abonelerin karar fonksiyonlarının önemli değişkenlerinden biri haline gelir ve operatörün mevcut ve gelecekteki konumunu şekillendirir. Aboneler sadece hizmetin kendisinden değil ilgili operatörün sahip olduğu kullanıc1 ağından da fayda sağlarlar (Frels, Shervani ve Srivastava 2003:30). Örneğin operatörlerin şebeke içi-şebeke dışı uyguladıkları farklı fiyat tarifeleri ve hususi belirlenen bazı alt guruplar arasındaki (aile, arkadaş.. vb.) iletişime

Makale Gecmiși / Article History

Başvuru Tarihi / Date of Application Kabul Tarihi / Acceptance Date
: 19 Ağustos / August 2019

: 20 Ekim / October 2019 
uyguladıkları indirimler tüketicilerin ilgili firmanın ağına atfettikleri değeri artırma çalışmalarıdır (Birke ve Swann, 2006:65). Potansiyel abone seçim yaparken ağ dışsallıkları yardımıyla daha az şebeke dışı ödeme yapabileceği ve aile ve yakın arkadaşları gibi sosyal çevresiyle daha uygun fiyata iletişim kurabileceği operatörü tercih etme eğilimdedir. A $\breve{g}$ dışsallıkları sabit iletişim hizmetleri için oldukça fazla ele alınmış ve incelenmiş olmasına rağmen mobil iletişimin öngörülenden hızlı şekilde büyümesi ve yayılması, veri ve zaman boyutu kısıtlarının olması bu piyasa için ağ dışsallıklarının ampirik analizlerini sınırlı tutmuştur (Srinivasan, Lilien ve Rangaswamy, 2004:41; Doganoglu ve Grzybowski, 2007:65).

Bu çalışmadaki amaç Türkiye Mobil Telekomünikasyon Piyasası'ndaki ağ dışsallıklarının varlığını ve etkilerini analiz etmektir. Çalışma Türkiye piyasası için olan ampirik analiz açığını gidermekte ve mobil iletişim piyasalarındaki ağ dışsallıklarını ele alan ampirik literatüre katkı sağlamaktadır. Çalışmada ikisi piyasa talebini ikisi de piyasa fiyatını dikkate alan dört farklı model Türkiye'deki mobil operatörlere ait 2005q1-2019q1 dönemleri arasındaki 57 çeyrek dönemlik panel veriler kullanılarak dinamik ortak korelasyonlu etkiler (dynamic common correlated effects, DCCE) tahmincisi aracılığıyla tahmin edilmektedir. Çalışma bu girişin ardından ikinci bölümde ağ dışsallıklarının tanım ve ele almakta ve üçüncü bölümde mobil telekomünikasyon piyasalarındaki ağ dışsallıklarını incelemektedir. Dördüncü bölümde ă̆ dışsallıkları literatürünün gelişimi dikkate alınarak önde gelen çalışmalar özet şekilde paylaşılmaktadır. Beşinci bölümde Türkiye Mobil Telekomünikasyon Piyasası en güncel piyasa verileri 1şığında anlatılmaktadır. Altınc1 bölüm ise ampirik analizin yapıldığı bölümdür. Burada öncelikle veri seti ve modeller tanıtılmakta, ardından kullanılan ekonometrik yol ve yöntemler hakkında bilgi verilmekte ve bu yöntemler dikkate alınarak tanımlanan modeller tahmin edilerek sonuçlar paylaşılmaktadır. Sonuç bölümünde elde edilen sonuçlar, amaç ve hedefler doğrultusunda değerlendirilmektedir.

\section{A $\breve{g}$ Dışsallıkları}

Ağ dışsallıkları konusuna ilk olarak Rohlf (1974) tarafından işaret edilmiş ancak kavram ilk Katz and Shapiro (1985) tarafından kullanılmıştır. Zaman içinde iktisat başta olmak üzere çeşitli disiplinlerden büyük ilgi gören ağ dışsallıklarının zaman zaman geniş ve genel zaman zamanda dar ve spesifik tanımları ortaya çıkmıştır. Daha öncede ifade edildiği gibi ağ dışsallıkları iktisatta dışsallık olarak incelenen ve bir aktörün tarafı olmadığı iktisadi bir faaliyetten pozitif veya negatif etkilenmesi olarak tanımlanan kavramın günümüz ağ endüstrileri için ele alınan özel bir şeklidir. Katz and Shapiro (1985; 424) ağ dışsallıklarını pozitif tüketim dışsallığı olarak ele alıp kullanıcıların malın tüketiminden elde ettiği ve diğer tüketicilerinde aynı malı tüketmesiyle artan fayda durumu olarak ifade etmektedir. Yine Katz ve Shapiro (1994;94) tarafindan ortaya konan diğer bir tanımda ăg dışsallıkları bir tüketici için bir ağın değerinin başka bir tüketicinin ağa katılması ve dolayısı ile ağın genişlemesi ile artması durumu olarak ele alınmaktadır. Yani ağ dişsallığından elde edilen fayda ă̆ büyüklüğü arttıkça daha da artmaktadır. Bir diğer tanımlamaya göre ise olumlu tüketim faydalarının uyumlu ürünler satın alan toplam tüketici sayısına bağlı olması durumudur (Church, Gandal ve Krause, 2002:2). Yani ağ dışsallığının oluşabilmesi için tüketicinin ilgili üründen kazandığı faydanın, yalnızca maldan kaynaklı değil aynı zamanda malı çevreleyen ağdanda fayda sağlanmalıdır (Katz ve Shapiro, 1985: 424 ; Farrell ve Klemperer, 2007:2009; Liebowitz ve Margolis, 1994:135; Shapiro ve Varian, 1998: 173; Schilling, 2002:387; Gallaugher ve Wang, 2002: 303).

Literatürde ağ dışsallıklarına artan ilgi ile piyasalardaki farklı etki ve sonuçlarını anlamak için, ortaya çıkan faydanın kaynağına göre çeşitli ağ dışsallıkları türleri tanımlanmıştır. Geleneksel olarak ağ dışsallıkları doğrudan ve dolaylı olmak üzere iki tür olarak sınıflandırılmaktadır. (Katz ve Shapiro, 1985; 424: Clements, 2004: 633). Sonradan yapılan çalışmalar ile kişisel ağ dışsallıkları isimli bir üçüncü tür de ortaya konmaktadır. Doğrudan ağ dışsallıklarında ilgili mal ya da hizmeti kullanan tüketici sayısı ile ağ dışsallığının değeri arasında doğru yönlü bir ilişki kurulur. Buna göre ilgili mal ya da ağın değeri sahip olduğu mevcut ya da potansiyel kullanıcı tabanının büyüklüğünden gelmektedir (Katz ve Shapiro, 1985: 424). Doğrudan ağ etkilerinde farklı tüketicilerin ağı kullanması tamamlayıcıdır, böylece her tüketicinin kullanmasının karşılığ1 ve kullanma eğilimi daha çok kullanıcıyı çekmektedir (Farrell ve Klemperer, 2007:2007 ). Bu tip ağ dişsallıkları telekomünikasyon, e-mail ve faks gibi hizmetlerle örneklendirilebilir. $\mathrm{Bu}$ tür hizmetler de her tüketicinin fayda fonksiyonu hizmeti kullanan tüketici sayısına bağlı olarak artmaktadır. Buna karşılık dolaylı ağ dışsallıkları söz konusu mal ya da hizmetin tamamlayıcı mal ya da hizmetlerine bağlı olarak oluşan etkileri ifade eder. Dolaylı ağ dışsallıkları ilgili malın tamamlayıcı unsurlarının olduğu piyasadaki firsatların ve alternatiflerin artırılması ile orantılıdır (Liebowitz 2002:13; Liebowitz ve Margolis. 1994:133; Church, Gandal ve Krause 2002:2). Yaz1lım ve donanımın birlikte kullanılması gereken piyasalar dolaylı ağ dışsallıklarının en temel örneklerindendir. İki bileşen, tüketim faydaları sağlamak için etkileşime girmekte veya bir araya getirilmektedir. Donanım birimi veya yazılımların, genellikle tek başına bir değeri yoktur veya nispeten çok az bir değere sahiptir. Birincil ürün olan donanımın tüketicisinin elde edeceği fayda tamamlayıcı ürün olan yazılımın piyasada daha fazla ve çeşitli olarak bulunması ile artar. Yani yazılım piyasası donanım piyasası için dolaylı ağ dışsallıkları oluşturmaktadır (Katz ve Shapiro, 1994:93: Gandal, 1995: 599; Gallaugher ve Wang, 2002: 303; Bonardi ve Durand, 2003:40; Clements, 2004: 633).

Ağ dışsallıklarının doğrudan ve dolaylı olarak sınıflandırılmasındaki en önemli özellik fayda fonksiyonundaki tüm tüketicilere aynı önemin verilmesidir. Bu yeni bir tüketiciyi ağa eklemenin, hali hazırda ağda bulunan tüm kullanıcıların yararını eşit ölçüde artırdığı anlamına gelmektedir. Çalışmalar ağ dışsallıklarının seviyesi ağa yeni katılan tüketiciye göre farklılaşabileceğini ortaya koymaktadır (Swann, 2002:417; Suarez, 2005:710; Birke ve Swann, 2006:65). Belirli bir operatörün abonesi olan bir cep telefonu kullanıcısı arkadaşlarının yada ailesinden birinin ağa katılmasından bir yabancının ağa dahil olmasından daha fazla fayda sağlar. Yani ağ dışsallıklarından doğan faydaları analiz etmek için 
dikkate alınması gereken farklı ağırlıklar vardır (Ahuja, 2000:425). Kişisel, yerel veya mikro ağ dışsallıkları bu türden ağ etkilerine atfen araştırmalarda kullanılan kavramlardır. Kişisel ağ dışsallıkları her ağ üyesinin fayda fonksiyonunda katkıda bulunma farklılıklarını dikkate alır. Bir kişinin belirli başka bir kişinin kullanıcı olmasından sağladığı etkiyi ifade eder. Tüketiciler, kendi alt gruplarıyla etkileşim kurarken, diğer guruplara nazaran daha fazla yarar sağlarlar. Dolayısıyla kişisel ağ dışsallıkları, ağ dışsallıklarının homojen olmadığı esasına dayanır (Ahuja, 2000: 425).

\section{Mobil Telekomünikasyon Piyasalarında Ăg Dışsallıkları}

Mobil telekomünikasyon piyasaları iletişimdeki sınırları kaldırma ve daha çok insanı birbirine bağlama çabası itibari ile ağ dışsallıklarının görüldüğü en tipik piyasa örneklerinden birisidir. Bu piyasada aboneler hizmetlerin kendisinden ziyade daha fazla bu hizmetlerin çevrelendiği abone ağından fayda sağlarlar (Frels, Shervani ve Srivastava 2003:30). Srinivasan, Lilien ve Rangaswamy (2004:41) çalışmalarına göre mobil telekomünikasyon piyasaları ağ dışsallıklarının yoğun olduğuna inanılan $45 \mathrm{mal} /$ hizmet piyasası listesinde en yüksek oranlara sahip piyasadır. Ekonomide ve sosyal hayatta oynadığı merkezi rol itibari ile mevcut ve potansiyel abonelerin kararlarını etkileyen ve dolayısı ile firma stratejilerine yön veren ve piyasanın şekillenmesinde önemli rol oynayan ă̆ dışsallıklarının mobil telekomünikasyon piyasalarının kendine has özelliklerinin de dikkate alınarak analiz edilmesi gerekir. Mobil telekomünikasyon piyasalarında bir hat satın alarak ağa katılma ve ağa katıldıktan sonra abonesi olduğu operatör aracılığıyla aramalar yaparak ağı kullanma olarak iki farklı talep tipinde de ağ dişsallıklarıyla karşılaşılmaktadır (Kar, 2019: Kim ve Kwon 2003:17; Birke ve Swann, 2006:66: Doganoglu ve Gryzbowski, 2007:65; Grajek, 2010: 130; Maicas, Polo ve Sese,2009a:160; Maicas, Polo ve Sese,2009b:544; Fuentelsaz, Maicas ve Polo, 2010:1)

Mobil piyasalarda doğrudan ve kişisel ağ dişsallıklarının güçlü şekilde gözlendiği söylenebilir (Kim ve Kwon 2003:17; Birke ve Swann 2006:66). Bu piyasada şebeke içi şebeke dışı uygulanan farklı fiyatlandırma tarifeleri ă̆ dışsallıklarının oluşmasının en önemli nedenidir. Mobil operatörler kendi tabanlarında bulunan bir abonenin yaptığı arama yine kendi tabanlarındaki başka bir aboneye gidiyorsa (şebeke-içi) daha düşük tarifeler uygularken aramalar alternatif başka bir operatörün tabanındaki bir aboneye yapılıyorsa (şebeke-dışı) daha yüksek tarifelerden ücretlendirmektedirler. Uygulanan bu strateji operatörün kendi tabanında yani ağında bir ağ dışsallığı oluşturmaktadır. Çünkü ağ ne kadar büyürse ağdaki abonelerin ortalama ödedikleri ücretler o kadar düşecektir. Örneğin sıklıkla iletişim kurulan aile bireyleri ya da yakın arkadaşlarla aynı operatör ağında bulunmak tüketicinin maliyetlerini düşürerek faydasını artıracaktır. Kişisel ağ etkilerinin önemini inceleyen Maicas, Polo ve Sese (2009a:160) göre bir kişinin bir operatörü tercih etme olasılığı o operatörün abonesi olan sosyal ağının üye sayısı ile doğru orantılıdır. Bu durum tüketicilerin geniş ağ tabanına sahip operatörlere yönelmelerine bir teşvik oluştururken büyük pazar payına sahip operatöründe daha yüksek fiyatlandırma yapmasına olanak sağlamaktadır. Ancak Birke ve Swann (2006) çalışmalarında şebeke-içi/şebeke-dışı fiyat farklılıklarının olmadığı durumlarda bile sosyal ağlardan kaynaklı olarak tüketici tercihlerinde ağ dışsallıklarının oluştuğunu ortaya koymaktadır (Doganoglu ve Gryzbowski, 2007:65; Grajek, 2010: 130; Fuentelsaz, Maicas ve Polo, 2010:1; Jang, Dai, ve Sung, 2005:133: Sobolewski ve Czajkowsi, 2012:198). Mobil iletişimde diğer türlere nazaran belki en az etkiyi oluşturan dolaylı ağ dışsallıklarıdır. Ancak iletişim kurdurmasının yanında GPS hizmeti bluetooth teknolojisi ya da kamera, parmak izi okuma, yüz tanıma gibi yeni teknolojik buluşları bünyesine dahil eden mobil iletişim piyasası birincil ürünün faydasını artıracak yeni uygulamalar, özellikler ve veya cihazlarla abonelere daha geniş ürün hizmet yelpazesi sunarak dolaylı ă̆ dışsallıklarından faydalanmaktadır.

\section{Literatür Taraması}

Ağ dışsallıklarıyla ilgili farklı yaklaşımları ortaya koyan geniş bir literatürden bahsetmek mümkündür. Rohlfs (1974) öncü çalışmasını takiben literatüre yön veren Katz ve Shapiro (1985) ve Farrell ve Saloner (1985) çalışmaları alanın ilkleri olarak kabul edilebilir. Rohlfs (1974) ağ dışsallıkları literatürüne temel oluşturan çalışmasında birbirine bağlı olarak değişen talep yapısının iktisadi analizini dışsal tüketim ekonomileri ifadesi ile ele almakta ve bu etkilerin ağ endüstrilerinin iktisadi analizindeki önemine dikkat çekmektedir. Katz ve Shapiro (1985) çıktı ve verimliliği dikkate alarak ağ dışsallıklarının üç farklı kaynağından bahsetmiş ve ağ endüstrisinde piyasa dengesinin oluşumunda tüketici beklentileri, firma prestiji ve kamu politikalarının belirleyici rollerine değinerek analizi derinleştirmiştir. Farrell ve Saloner (1985) ise piyasadaki ürünlerin standardizasyonu ve uyumluluğunun iktisadi etkilerini ele alarak daha çok dolaylı ağ dişsallıklarına vurgu yapmış ve ağ endüstrilerindeki tüketiciler için ürünün değerinin ürünün diğer ürünlerle uyumlu olmasına ve tamamlayıcı mal seçeneklerinin artmasına bağlı olarak yükseldiğini göstermişlerdir.

Öncü çalışmaları takiben literatür ağ dışsallıklarının varlığını, derecesini ve etkilerini analiz eden bir çok teorik ve ampirik çalışmayla geniş̧lemiştir. Economides ve Himmelberg (1995) çalışmalarında ABD'de 1978-1991 yılları arasında faksa olan talebi ele almakta ve beklenen ağ büyüklüğünün geçmiş ağ büyüklüğünün doğrusal bir fonksiyonu olacağını ifade etmektedirler. Yazarlar çalışmalarında (Economides ve Himmelberg, 1995) 1980 sonlarında faks pazarının hızlı büyümesinin ă̆ dışsallıklarından etkilendiğini ortaya koymuşlardır. Goolsbee and Klenow (1999) çalışmalarında ABD’deki 110,000 hane halkının 1997 yılına ait verilerini kullanarak ev bilgisayarlarının yayılmasında ağ dışsallıklarının etkisini incelemişlerdir. Birçok farklı özelliklerin dikkate alındığı çalışma sonucunda ilk kez ev bilgisayarı almanın ev bilgisayarlarının yaygın olarak kullanıldığı bölgelerde ya da sosyal çevrenin yaygın şekilde şahsi bilgisayara sahip olduğu sosyal topluluklarda daha yaygın olduğu sonucunu elde etmişlerdir. Ohashi (2003) ABD'deki videokaset kaydedici (VCR) piyasasındaki ağ dışsallıklarının etkilerini incelemiştir. Ohashi (2003) çalışmasında 1978 ve 1986 yılları arasındaki 
verileri kullanarak üç farklı analiz gerçekleştirmiş ve çalışmada ilgili dönemde dolaylı ağ dışsallıklarının etkisiyle Beta formatın VHS'e karşı olan mücadelesini kaybettiğini ve bu nedenle 1989 da piyasadan çekildiğini göstermiştir.

Ağ dışsallıklarının gözlendiği ağ endüstrisindeki optimal fiyatlandırma stratejilerini ele alan çalışmalarda son yıllarda artmaya başlamıştır. Candoğan, Bimpikis ve Özdağlar (2012) çalışmalarında geliştirdikleri model yardımıyla belirli bir ağın tabanında yer alan ve birbirlerinin tüketim kararlarından etkilenen tüketicilerin sosyal etkileşimlerinin bir fonksiyonu olarak optimal fiyatlandırma stratejilerini incelemektirler. Elde ettikleri bulgulara göre her tüketicinin kullanım seviyesi ağdaki doğrudan tanıdıklarının o ağ yapısındaki kullanımına bağlıdır. Bu nedenle yapılacak fiyatlama tüketicinin ilişkili olduğu diğer guruplardaki tüketimi de etkileyecektir. Fainmesser ve Galeotti (2016) ise çalışmalarında firmaların karlı fiyatlandırma stratejileri tasarlamak için tüketicilerin birbirinden farklılaşan etkileri ile ilgili bilgileri nasıl kullandıklarını analiz etmektedir. Tüketicilerin diğer tüketicilerin seçimlerinden etkilendiği ve bazı tüketicilerin diğerlerinden daha etkili olduğu ve oligopol piyasadaki firmaların yatay olarak farklılaşmış ürünleri sattığı bir model geliştirmişlerdir. Firmaların, etki düzeyi ortalamanın üstünde olan tüketicileri etkileme gücü ortalamanın altında olan tüketicilerden aldığ1 yüksek ücretlerle sübvanse ettiğini göstermişlerdir. İndirimlerin ve yüksek ücretlendirmenin büyüklükleri, ağ dışsallıklarının gücüne ve firmaların sahip olduğu bilgi seviyesine bağlıdır.

Ağ endüstrilerinin tipik örneklerinden olan mobil telekomünikasyon piyasalarında ăg dişsallıklarını analiz eden literatür çok zengin olmasa da dünyada ki önde gelen piyasaları ele alan çalışmalar söz konusudur. Kim ve Kwon (2003) çalışmalarında ă̆ dışsallıklarını dikkate alarak yeni abonelerin kazanılmasında ă̆ boyutunun avantajını Kore Mobil telekomünikasyon Piyasası örneği ile ampirik olarak analiz etmişlerdir. Piyasada operatörler arası tam uyumluluk olduğundan dolayı ağ dışsallıklarının etkisi noktasında şüphe duyan yazarlar yeni abonelerin servis sağlayıcılarını seçtiğinde ağ boyutunun önemli olup olmadığını test etmişlerdir. Ampirik analizde Kore'deki beş farklı mobil operatöre ait 1335 abone ile 1999 yılında yapılan anketten elde edilen veriler kullanılmıştır. Çalışma sonucunda ağ dişsallıkları etkisinin gözlendiği ve şebeke içi indirimli iletişim avantajları ve daha kaliteli ve yüksek erişilebilirlik gibi avantajlar nedeniyle yeni tüketicilerin daha fazla sayıda aboneye sahip olan operatörü tercih ettikleri ortaya konmaktadır. Doganoglu and Grzybowski (2005) çalışmalarında Ocak 1998'den Haziran 2003'e kadar olan dönemde Almanya'daki mobil telekomünikasyon hizmetlerine olan talebi incelenmişler ve endüstrisindeki ağ dışsallıklarının etkilerini tahmin etmişlerdir. Bu dönemde Almanya'da toplam abone tabanı yaklaşık \%700 artarken, fiyatlar sadece \%41 oranında azalmıştır. Elde edilen sonuçlara göre ağ dışsallıkları Almanya'daki mobil hizmetlerin yayılmasında önemli bir rol oynamaktadır. Ağ dışsallıklarının yokluğunda, fiyatlar gözlemlendiği gibi kalırsa, cep telefonu penetrasyonu en az \%50 daha düşük olacaktır. Macias, Polo, ve Sese, (2009a) çalışmalarında İspanya mobil telekomünikasyon endüstrisinde mobil kullanıcılarının tercihlerinde kişisel ağ dişsallıklarının rolünü incelemişlerdir. Sonuçlar, kişisel ağ dışsallıklarının mobil kullanıcıların seçimini belirlemede kilit bir rol oynadığını ortaya koymaktadır. Kişisel ağ dışsallıklarıyla ilgili olarak, bir müşterinin belirli bir şirketi seçme olasılığının, o firmaya zaten abone olan sosyal ağ üyesi sayısı ile arttığı tespit edilmiştir. Sobolewski ve Czajkowski (2012) ve Grajek (2010) Polonya Mobil telekomünikasyon Piyasası'ndaki ağ dişsallıklarını analiz etmişlerdir. Grajek (2010) mobil iletişimde ağ dışsallıklarının ve ağlar arası uyumluluğun tanımlanmasını kolaylaştıran yapısal bir talep modeli geliştirmiştir. Model 1996-2001 yıllarına ait üç aylık panel verilerini kullanarak tahmin edilmiş ve sonuçta çok güçlü ağ dışsallıkları ve mobil telefon şebekelerinin birbirleriyle tam bağlantılarına rağmen, düşük uyumluluk bulunmuştur. Ayrıca ağ dışsallıklarını göz ardı etmenin talep esnekliğinin fazla tahmin edilmesine yol açtığı da ortaya konmuştur. Sobolewski ve Czajkowski (2012) çalışmasında tüketicilerin gözlemlenebilir ve gözlemlenemez tercih heterojenliğini hesaplayarak ağ dışsallıklarının tüketiciler arasındaki kaynaklarını ve değişkenliğini analiz etmiştir. Sonuçlardan, aynı operatörü kullanan tüketicilerin sosyal ağ grubunun oranı ve net fiyat indirimlerinin büyüklüğü ile ilgili güçlü ağ dışsallıklarının varlığı tespit edilmiştir.

Literatürde Türkiye Mobil Telekomünikasyon Piyasası'ndaki ağ dışsallıklarını ele alan tek çalışma bilindiği kadarıyla Karaçuka'nın (2009) mobil iletişim talebinin belirleyicilerini analiz ettiği çalışmadır. Karaçuka (2009) ağ dişsallıklarını “şebeke etkileri” olarak ele almakta ve Türkiye'de mobil iletişim talebinin önemli belirleyicilerinden olduğunu ortaya koymaktadır. Çalışmada oluşturulan model 2002-2006 yılları arasındaki aylık zaman serileri kullanılarak her operatör için ayrı ayrı EKK yöntemi ile tahmin edilmektedir. Elde edilen sonuçlara göre ağ dışsallıkları operatörlerin tüketici tabanlarını ve piyasa güçlerini açıklayan en önemli faktör olarak belirlenmiş ve piyasa fiyatlarının belirlenmesinde etkili olduğu vurgulanmıştır. Burada yapılan çalışmanın Karaçuka'nın (2009) çalışmasından en önemli farklılıkları kullanılan modeller, dikkate alınan zaman dilimi, yararlanılan veri seti ve türü ve tercih edilen tahmin yöntemidir.

\section{Türkiye Mobil Telekomünikasyon Piyasası}

Dünyanın önde gelen ülkelerinde olduğu gibi Türkiye'de de mobil telekomünikasyon piyasası hızlı şekilde gelişerek ülkenin lider piyasalarından biri haline gelmiştir. Türkiye Mobil Telekomünikasyon Piyasası'nda ilk yıllarda yeni girenler ve birleşmelerle zaman zaman operatör sayısı değişiklik gösterse de 2005 yılından beri üç operatörlü olarak hizmet verilmektedir. Hali hazırda piyasada yer alan Turkcell, Vodafone ve TT Mobil operatörleri 2019 y1lının birinci çeyreği verilerine göre sırası ile piyasanın (abone sayısına göre) \%41.6, \%31.1 ve \%27.3’üne sahiptir. Aynı dönem itibarıyla gelire göre pazar payları incelendiğinde ise Turkcell'in pazar payının \%40.4, Vodafone'un pazar payının \%37 ve TT Mobil'in pazar payının ise \%22.6 seviyelerinde olduğu görülmektedir. Toplam yaklaşık 81 milyon mobil abonenin bulunduğu piyasada penetrasyon oranı \%98.7'dir. Bu oran $0-9$ yaş nüfus düşülerek hesaplandığında ise \%110.9'dur. Piyasadaki toplam abone sayısının \%42.5'ini ön ödemeli ve \%57.5'ini faturalı aboneler oluşturmaktadır. Bu abonelerin yaklaşık \%87.8'i bireysel ve \%12.2'si ise kurumsal abonelerdir. 2019 y1lı birinci çeyrekte 23.72 milyar dakikası 
Turkcell'den, 23.29 milyar dakikası Vodafone'dan ve 19.10 milyar dakikası TT Mobil'den olmak üzere toplam mobil trafik hacmi 66.11 milyar dakika olarak gerçekleşmiştir. Operatörlerin abone başına aylık ne kadar gelir elde ettiklerini gösteren ARPU değerleri 2019 yılının 1. çeyreğinde Turkcell için 34.9 TL, Vodafone için 32.2 TL, TT Mobil için ise 30.3 TL'dir. Abonelerin aylık ortalama arama dakikalarını gösteren MoU değerlerine bakıldığında aynı dönemde Turkcell'in 454 dakika, Vodafone'un 512 dakika ve TT Mobil'in ise 476 dakika olarak gerçekleşmiştir. Türkiye ortalaması ise 448 olarak hesaplanmıştır (BTK, 2019a; BTK,2019b).

\section{Ampirik Analiz}

Bu çalışmanın amacı mobil telekomünikasyon piyasalarındaki ağ dışsallıklarının varlığını ve etkilerini Türkiye örneği ile analiz etmektir. Ampirik analizde Türkiye Mobil İletişim Piyasası'na ait 2005q1-2019q1 dönemlerini kapsayan 57 çeyrek dönemlik veriler kullanılarak dinamik ortak korelasyonlu etkiler (dynamic common correlated effects, DCCE) tahmincisi ile uzun dönem tahminleri yapılmaktadır. İkisi piyasa talebini ikisi de piyasa fiyatını temsil eden dört farklı model yardımı ile doğrudan ve sosyal ağ dişsallıklarının etkileri ortaya konmaktadır. Model tahminlerine geçmeden önce modeller için yatay kesit bağımlılığının, homojenliğin ve eşbütünleşme ilişkisinin analiz edilmesi ve ayrıca değişkenlerin birim kök içerip içermediğinin belirlenmesi gerekmektedir. Aşağıda veri ve modellerle ilgili bilgiler paylaşıldıktan sonra öncelikle ampirik analizde kullanılan test ve yöntemlerin sıralı özet metodolojisi verilmekte ve ardından analizlere geçilmektedir.

\subsection{Veri ve Model}

Analizde ă̆ dışsallıklarının varlığı ve etkileri talep miktarı ve piyasa fiyatı üzerinden analiz edilecektir. Çalışmada Economides ve Himmelberg (1995) ve Shew (1994) tarafindan ortaya konan ve Grajek (2003) ve Baraldi (2012) tarafından geliştirilerek ağ dişsallıklarının analizinde tercih edilen modeller bu çalışmaya uyarlanarak kullanılacaktır. $q$ mikatarı, $p$ fiyatı, $y$ kişi başına geliri ve $c$ piyasa yoğunlaşmasını göstermek üzere analiz için temel alınan modellerin genel görünümü aşağıdaki gibidir;

$$
\begin{aligned}
& q_{i t}=q_{i t-1}+c_{t-1}+p_{i t}+y_{t} \\
& p_{i t}=q_{i t-1}+c_{t-1}+y_{t}
\end{aligned}
$$

Genel modeller geçmiş dönem talep miktarının ve piyasa yoğunlaşmasının mevcut dönem satın almaya ve fiyatlara etkisini göstermektedir. Bu modellerden hareketle ağ dışsallıklarının talep miktarına ve piyasa fiyatına olan etkisi (2) nolu modellerle analiz edilecektir.

$$
\begin{aligned}
& \text { Model I : } n s_{i t}=n s_{i t-1}+\operatorname{con}_{t-1}+r p m_{i t}+g d p_{t}+u_{i t} \\
& \text { Model II : } \operatorname{mou}_{i t}=\operatorname{mou}_{i t-1}+\operatorname{con}_{t-1}+r p m_{i t}+g d p_{t}+u_{i t} \\
& \text { Model III : } \operatorname{rpm}_{i t}=n s_{i t-1}+c o n_{t-1}+g d p_{t}+u_{i t} \\
& \text { Model IV : } \operatorname{rpm}_{i t}=\operatorname{mou}_{i t-1}+\operatorname{con}_{t-1}+g d p_{t}+u_{i t}
\end{aligned}
$$

Bu modellerde ns abone sayısını göstermekte ve ağa katılma talebini temsil etmektedir, mou aylık ortalama kullanımı göstermekte ve ağı kullanma talebini temsil etmektedir, rpm operatörlerin dakika başına ortalama gelirini göstermekte ve piyasa fiyatını temsilen kullanılmaktadır, con piyasa yoğunlaşmasını göstermekte ve abonelerin şebeke içi görüşme olasılıklarını temsil etmektedir ve $g d p$ ise kişi başına GSYH’yı göstermekte ve geliri temsilen kullanılmaktadır. Piyasa yoğunlaşmasını temsil eden con değişkeni yerine modellerde piyasadaki firmaların pazar paylarının karelerinin toplanması ile elde edilen Herfindahl-Hirschman Endeksi (HHI) ve piyasadaki en büyük firmanın pazar payını esas alan Concentration Ratio 1 (CR1) değerleri modellere ayrı ayrı konularak tahmin yapılacaktır. Yani yukarıda gösterilen her model için $h h i$ değişkenli ve $c r l$ değişkenli olmak üzere iki farklı versiyon tahmin edilecektir.

Mobil iletişim için ağa katılma ve ağı kullanma talebi olarak iki talep türünden söz edilebilir (Kar,2019). Ağa katılma talebi herhangi bir operatörden mobil hat satın alarak piyasaya abone olarak girmeyi ifade eder ve modellerde abone sayısı $(n s)$ ile ölçülür. Ağ̊ kullanma talebi ise abone olarak piyasaya dahil olan tüketicinin aylık ortalama yaptı̆̆ 1 arama dakikalarını ifade eder ve modellerde aylık ortalama kullanım (mou) ile ölçülür. Model I (Economides ve Himmelberg, 1995; Kim and Kwon, 2003) geçmiş dönemdeki ağa katılma talebi ve piyasa yoğunlaşmasının yeni aboneliklere etkisini ve Model II (Macias, Polo, ve Sese, 2009a) geçmiş dönemdeki ağı kullanma talebi ve piyasa yoğunlaşmasının hali hazırdaki kullanıma etkilerini gözlemleyerek ağ dışsallıklarının talep miktarına etkisini analiz etmektedir. Geçmiş dönemdeki ağa katılma talebinin ( $\left.n s_{i t-1}\right)$ mevcut dönemdeki ağa katılma talebine $\left(n s_{i t}\right)$ etkisi doğrudan ağ dişsallıklarını göstermektedir. Geçmiş dönemdeki ağı kullanım talebinin $\left(m^{\prime} u_{i t-1}\right)$ mevcut dönemdeki ağı kullanım talebine $\left(m_{0} u_{i t}\right)$ etkisi abonelerin daha çok sosyal çevreleri ile düzenli iletişime geçtikleri için sosyal ă̆ dışsallıklarını göstermektedir. Modellerdeki geçmiş dönem piyasa yoğunlaşmasının ( con $\left._{i t-1}\right)$ mevcut dönemdeki ağa katılma ve ağı kullanma taleplerine etkisi piyasa az sayıda, yüksek pazar payına sahip operatörlerden oluştukça, yani piyasa yoğunlaşması artıkça, abonelerin sosyal çevreleri ile aynı operatör ağında bulunma olasılıklarını artıracağından sosyal ağ dışsallıklarına işaret edecektir.

Model III ve Model IV (Brynjolfsson ve Kemerer, 1996; Candoğan, Bimpikis ve Özdağlar, 2012) fiyatı temsilen kullanılan dakika başına gelir $\left(r p m_{i t}\right)$ yardımıyla geçmiş dönemdeki ağa katılma $\left(n s_{i t-1}\right)$, ağı kullanma $\left(\right.$ mou $\left._{i t-1}\right)$ taleplerinin ve piyasa yoğunlaşmasının ( $\left.\operatorname{con}_{i t-1}\right)$ fiyata olan etkisini ağ dışsallıkları bağlamında ele almaktadır. Geçmiş dönemde gerek 
aboneliklerde gerekse kullanımda çokça tercih edilen operatör abonelerinin ödeme istekliliğinin yüksek olduğu değerlendirmesi yapar ve fiyatları bu durumu dikkate alarak belirler. Ayrıca piyasaların az sayıda, pazar payı yüksek operatörlerden oluşması, yani yüksek yoğunlaşma durumunda, abonelerin sosyal ağlarının aynı operatör tabanında toplanma olasılığını artırır. Böylece abonelerin şebeke içi daha düşük fiyatlardan iletişim kurabilme imkânı artar. Bu durumu iyi analiz eden operatörler tüketicinin bu dışsallığından elde ettikleri avantajın bir kısmını kendilerine transfer emek amacı ile fiyatları yükseltirler.

Model tahminleri sonucunda modellerde yer alan katsayılar ile ilgili beklentiler aşağıdaki gibidir;

Model I ve Model II'de geçmiş dönem talep miktarının ( $n s_{i t-I}$ ve mou $\left._{i t-1}\right)$ ve piyasa yoğunlaşmasının $\left(\right.$ con $\left._{i t-I}\right)$ katsayılarının ă̆ dışsallıklarının varlığı durumunda pozitif $(+)$ olması beklenir. Fiyat değişkeninim $\left(r p m_{i t}\right)$ katsayısının talep kanununa uygun olarak negatif (-), gelir değişkeninin $\left(g d p_{i t}\right)$ katsayısının normal mallara uygun olarak pozitif $(+)$ olması beklenmektedir.

- $\quad$ Model III ve Model IV'de ağ dişsallıklarının varlığı durumunda operatörlerin geçmiş dönem talep miktarının büyüklüğü nispetinde daha yüksek fiyat uygulayacağı düşünülerek geçmiş dönem talep miktarı değişkenlerinin $\left(n s_{i t-1}\right.$ ve mou $\left._{i t-1}\right)$ katsayılarının talep kanunundan saparak pozitif $(+)$ olması beklenir. Piyasa yoğunlaşmasının daha uygun olan şebeke içi görüşmeleri kolaylaştıracağı ve firmaların rekabetten uzaklaşan yapıyı daha fazla kar elde etmek için kullanacağı için $\left(\operatorname{con}_{i t-l}\right)$ katsayısının pozitif $(+)$ olması beklenir. Gelir değişkeninin $\left(g d p_{i t}\right)$ katsayısının da gelir ile ödeme istekliliğinin artacağından pozitif $(+)$ olması beklenir.

Tablo 1. Değișken Tanımları ve Kaynaklar

\begin{tabular}{|c|c|c|c|}
\hline Değişken & Tanım & Hesaplanması & Kaynak \\
\hline$n s$ & Toplam abone sayıs1 & $\begin{array}{l}\text { Bir operatörün mobil hattına sahip olarak ağ tabanında bulunan } \\
\text { toplam abone sayısıdır. }\end{array}$ & $\begin{array}{l}\text { BTK, Turkcell, } \\
\text { Vodafone, TT Mobil }\end{array}$ \\
\hline mou & Aylık ortalama kullanı & $\begin{array}{l}\text { Mobil hatta sahip abonelerin aylık ortalama giden arama miktarıdır. } \\
\text { Toplam giden arama trafiğginin toplam abone sayısına bölünmesi il } \\
\text { elde edilir. (dakika) }\end{array}$ & $\begin{array}{l}\text { BTK, Turkcell, } \\
\text { Vodafone, TT Mobil }\end{array}$ \\
\hline rpm & Dakikası başına gelir & $\begin{array}{l}\text { Operatörlerin giden arama dakikası başına elde ettikleri gelir. } \\
\text { Operatörlerin mobil iletişimden elde ettikleri toplam gelirin toplam } \\
\text { giden trafiğe bölünmesi ile elde edilir. }\end{array}$ & $\begin{array}{l}\text { BTK, Turkcell, } \\
\text { Vodafone, TT Mobil }\end{array}$ \\
\hline hhi & $\begin{array}{l}\text { Herfindahl-Hirschman } \\
\text { Endeksi }\end{array}$ & $\begin{array}{l}\text { Operatörlerin pazar paylarının karelerinin } \\
\text { toplanması ile elde edilir. }\end{array}$ & $\begin{array}{l}\text { BTK, Turkcell, } \\
\text { Vodafone, TT Mobil }\end{array}$ \\
\hline$c r l$ & $\begin{array}{l}\text { CR1 Yoğunlaşma } \\
\text { Endeksi }\end{array}$ & $\begin{array}{l}\text { Mobil piyasadaki en yüksek pazar payına sahip operatörün pazar } \\
\text { payıdır. }\end{array}$ & $\begin{array}{l}\text { BTK, Turkcell, } \\
\text { Vodafone, TT Mobil }\end{array}$ \\
\hline$g d p$ & Kişi başına GSYH & Toplam GSYH'nın toplam nüfusa bölünmesi ile elde edilir. & TCMB \\
\hline
\end{tabular}

\subsection{Ekonometrik Metodoloji}

\subsubsection{Yatay Kesit Bağımlılığı Testi}

Ampirik analize başlarken öncelikle yatay kesit bağımlılığg test edilerek paneli oluşturan yatay kesit birimleri arasındaki korelasyon incelenmelidir. Yatay kesit bağımlılığ Breusch ve Pagan (1980) LM testi, Pesaran (2004) scaled LM testi, Baltagi, Feng ve Kao (2012) Bias-adjusted scaled LM testi ve Pesaran (2004) CD testleri kullanılarak araştırılacaktır. Bu çalışmada $\mathrm{T}>\mathrm{N}$ olduğundan Breusch ve Pagan (1980) LM testi esas alınacaktır.

Bu dört test içinde aşağıdaki (3) nolu hipotezler yazılabilir;

$$
H_{0}: \rho_{i j}=\operatorname{corr}\left(u_{i t}, u_{j t}\right)=0(i \neq j) \quad H_{1}: \rho_{i j}=\operatorname{corr}\left(u_{i t}, u_{j t}\right) \neq 0 \quad(i \neq j)
$$

$\mathrm{Bu}$ hipotezlerde yer alan $\rho_{i j} i$. ve $j$. yatay kesit biriminin kalıntıları arasındaki korelasyon katsayısını temsil etmektedir. Bu noktada temel hipotez yatay kesit birimleri arasında korelasyonun yokluğunu gösterirken alternatif hipotez yatay kesit bağımlılı̆̆ını ifade etmektedir.

Breusch ve Pagan (1980) Lagrange Çarpanı (LM) test istatistiği aşağıdaki gibi hesaplanmaktadır:

$$
L M=T \sum_{i=1}^{N-1} \sum_{J=i+1}^{N} \widehat{\rho}_{i j}^{2}
$$

\subsubsection{Homojenlik Testi}

Eşbütünleşme denkleminde yer alan eğim katsayılarının birimlere göre homojen olup olmadığı bu çalışmada Pesaran ve Yamagata (2008) tarafından önerilen ve Swamy testinin standartlaştırılmış versiyonu olan homojenlik testlerinden yararlanılarak analiz edilecektir. Pesaran ve Yamagata (2008) eğim parametrelerinin homojenliğini büyük örneklemler için önerilen $(\widehat{\Delta})$ küçük örneklemler için önerilen $\left(\tilde{\Delta}_{a d j}\right)$ iki farklı test versiyonu ile test etmektedir. $\mathrm{H}_{0}$ hipotezin homojenliği ifade ettiği ve $\mathrm{H}_{1}$ hipotezin heterojenlik üzerine kurulduğu test hipotezleri aşağıdaki gibi ifade edilebilir: 


$$
H_{0}: \beta_{i}=\beta \text { tüm i'ler için } \quad H_{1}: \beta_{i} \neq \beta_{j}
$$

Birinci versiyon $(\widehat{\Delta})$ ve ikinci versiyon $\left(\tilde{\Delta}_{a d j}\right)$ için test istatistikleri aşağıdaki gibi hesaplanır:

$$
\hat{\Delta}=\sqrt{N}\left(\frac{N^{-1} \hat{S}-k}{\sqrt{2 k}}\right) \quad \tilde{\Delta}_{a d j}=\sqrt{N}\left(\frac{N^{-1} \tilde{S}-E\left(\tilde{Z}_{i T}\right)}{\sqrt{\operatorname{Var}\left(\tilde{Z}_{i T}\right)}}\right)
$$

\subsubsection{Panel Birim Kök Testi}

Çalışmada yatay kesitsel olarak değişken (variant variables) ve yatay kesitsel olarak sabit olan değişkenler (invariant variables) kullanılmaktadır. Bundan dolayı bu iki gurup için farklı birim kök testleri kullanılacaktır. Yatay kesitsel olarak değişken olan değişkenler için CIPS testi (Pesaran, 2007) ve yatay kesitsel olarak değişken olmayan değişkenler için Genelleştirilmiş Dickey-Fuller (ADF) testi (1979) kullanılmaktadır.

Pesaran (2007) tarafindan geliştirilen CIPS testi ikinci nesil birim kök testlerinden biridir. Otokorelasyonun olmadığı durumda dinamik heterojen panel veri modeli aşă̆ıdaki gibidir;

$Y_{i t}=(1-\phi) \mu_{i}+\phi_{i} Y_{i t-1}+u_{i t} \quad, i=1, \ldots, N ; t=1, \ldots, T$

$u_{i t}$ hata terimi olmak üzere, tek bir faktör yapısına sahiptir ve aşağıdaki gibi ifade edilebilir:

$u_{i t}=\gamma_{i} f_{t}+\varepsilon_{i t}$

$f_{t}$, gözlenemeyen ortak etki ve $\varepsilon_{i t}$ bireysel spesifik hata terimi olmak üzere, (9) nolu eşitlik aşağıdaki gibi yazılabilir:

$\Delta Y_{i t}=\alpha_{i}+\beta_{i} Y_{i t-1}+\gamma_{i} f_{t}+\varepsilon_{i t}$

(10) no'lu denklemde $\alpha_{i}=(1-\phi) \mu_{i}, \beta_{i}=-1\left(1-\phi_{i}\right)$ ve $\Delta Y_{i t}=Y_{i t}-Y_{i t-1}$ olmak üzere durağanlığı sinamak üzere hipotezler aşağıdaki gibidir:

$H_{0}: \beta_{i}=0 \quad$ (tüm i'ler için)

$H_{1}: \beta_{i}<0 \quad\left(i=1,2, \ldots, N, \quad \beta_{i}=0, \quad i=N_{1}+1, N_{1}+2, \ldots, N_{1}+N\right)$

Pesaran (2007), CIPS test istatistiğini, IPS (2003) testinin yatay kesitsel olarak genişletilmiş bir versiyonu olarak aşağıdaki gibi ifade edilmektedir (Pesaran, 2007):

$\operatorname{CIPS}(N, T)=t-\operatorname{bar}=N^{-1} \sum_{i=1}^{N} t_{i}(N, T)$

Yatay kesitsel olarak değişken olmayan değişkenlerin durağanlı̆̆ı Genelleştirilmiş Dickey-Fuller (ADF) testi (1979 ile test edilmektedir. ADF testi aşağıdaki modelleri kullanmaktadır;

$$
\begin{aligned}
& \Delta X_{t}=\beta_{0}+\beta_{1} X_{t-1}+\sum_{i=1}^{k} \lambda_{i} \Delta X_{t-i}+u_{t} \\
& \Delta X_{t}=\beta_{0}+\beta_{1} X_{t-1}+\beta_{2} \text { trend }+\sum_{i=1}^{k} \lambda_{i} \Delta X_{t-i}+u_{t}
\end{aligned}
$$

\subsubsection{Eşbütünleşme Testi}

Model katsayılarının tahminine geçmeden önce son olarak eşbütünleşme testleri yapılarak seriler arasında uzun dönemli bir ilişkinin olup olmadığı test edilir. Bu çalışmada Westerlund (2008) tarafından geliştirilen hem yatay kesit bağımlılığını dikkate alan hem de eğim katsayılarının heterojen olmasına izin veren Durbin Hausman $(D H)$ eşbütünleşme testi kullanilacaktır.

$D H$ testinin biri panel boyutu ve diğeri grup boyutu olmak üzere iki boyutu vardır. $D H$ paneli $\left(D H_{p}\right)$ testinin varsayımı, otoregresif parametrenin her kesit için ortak olmasıdır. Bu varsayımla, boş hipotez reddedildiğinde, tüm kesitler için eşbütünleşme olduğu söylenir. $D H$ grubu $\left(D H_{g}\right)$ testi, otoregresif parametrenin alternatif hipotez altında kesitler arasında değişmesine izin verir. Bu nedenle, boş hipotezin reddedilmesi, bazı kesitler için eşbütünleşmenin olduğunu göstermektedir (Westerlund, 2008). $D H_{p}$ ve $D H_{g}$ test istatistikleri ve hipotezler aşağıdaki gibidir;

$$
\begin{array}{rlrl}
D H_{p} & =\hat{S}_{N}(\tilde{\phi}-\hat{\phi})^{2} \sum_{i=1}^{N} \sum_{t=2}^{T} \hat{e}_{i, t-1}^{2} & D H_{g}=\sum_{i=1}^{N} \hat{S}_{i}\left(\tilde{\phi}_{i}-\hat{\phi}_{i}\right)^{2} \sum_{t=2}^{T} \hat{e}_{i, t-1}^{2} \\
H_{0}: \phi_{i}=1 \text { (tüm i'ler için) } & H_{0}: \phi_{i}=1 \text { (tüm i'ler için) } \\
H_{1}: \phi_{i}=\phi \text { ve } \phi<1 \text { (tüm i'ler için) } & H_{1}: \phi_{i}<1 \text { (en azından bazl i'ler için) }
\end{array}
$$

\subsubsection{Panel Eşbütünleşme Katsayılarının Tahmini}


Chudik ve Pesaran (2005) ikinci nesil tahmincilerden CCE'i geliştirerek Dinamik Ortak Korelasyonlu Etkiler (Dynamic Common Correlated Effects, DCCE) tahmincisini ortaya koymuştur. DCCE tahmincisinde değişkenlerin yatay kesit ortalamaları gözlenmeyen faktörleri temsil etmek üzere modele dahil edilmektedir.

Chudik ve Pesaran (2005) tarafından önerilen dinamik heterojen panel veri modelinin genel görünümü aşağıdaki gibidir:

$y_{i t}=c_{y i}+\phi_{i} y_{i t-1}+\beta_{0 i}^{\prime} x_{i t}+\beta_{1 i}^{\prime} x_{i t-1}+u_{i t}$

(14)

$$
u_{i t}=\gamma_{i}^{\prime} f_{t}+\varepsilon_{i t}
$$

(14) ve (15) no'lu denklemlerde, $i=1,2, \ldots, N$ ve $t=1,2, \ldots, T$, olmak üzere $y_{i t}$, bağımlı değişken, $x_{i t}$ bağımsız değişkenlerdir. $c_{y i}$, her bir yatay kesit birimi için bireysel sabit etkileri, $x_{i t}, t$ döneminde yatay kesit birimlerine $(i)$ özgü bağımsız değişkenlerin $k_{x} x 1$, vektörü, $f_{t}$, gözlemlenmeyen ortak faktörlerin $m x l$ vektörü ve $\varepsilon_{i t}$ ise hata terimidir. Chudik ve Pesaran (2005) modele dahil edilen yatay kesit ortalamalarında gecikme sayısı $p_{T}$ olmak üzere, $p_{T}=T^{(1 / 3)}$ olarak ifade etmektedir.

\subsection{Tahmin Sonuçlart}

Yatay kesit bağımlılığı tüm modeller için Breusch ve Pagan (1980) LM, Pesaran (2004) scaled LM, Baltagi, Feng ve Kao (2012) Bias-adjusted scaled LM ve Pesaran (2004) CD testleri kullanılarak test edilmiş ve sonuçlar Tablo 2'de paylaşılmıştır. Paylaşılan dört test sonucuna göre de tüm modeller için yatay kesit bağımlılığının olmadığını ifade eden $H_{0}$ hipotezi 0.05 anlamlılık düzeyinde reddedilmektedir. Yani yatay kesit birimleri arasında korelasyon vardır. Bu sonuç sadece üç operatörle oligopol olarak yapılanan bir piyasa için beklentilerle oldukça uyumludur.

Tablo 2. Yatay Kesit Bağımlılı̆̆ı Testi Sonuçları

\begin{tabular}{|c|c|c|c|c|c|c|c|c|}
\hline \multirow[b]{2}{*}{ Testler } & \multicolumn{2}{|c|}{ Model I } & \multicolumn{2}{|c|}{ Model II } & \multicolumn{2}{|c|}{ Model III } & \multicolumn{2}{|c|}{ Model IV } \\
\hline & $a$ & $b$ & $a$ & $b$ & $a$ & $b$ & $a$ & $b$ \\
\hline \multirow[t]{2}{*}{ Breusch-Pagan LM } & 32.307 & 43.988 & 43.019 & 51.486 & 105.05 & 88.256 & 33.344 & 37.515 \\
\hline & $(0.000)$ & $(0.000)$ & $(0.000)$ & $(0.000)$ & $(0.000)$ & $(0.000)$ & $(0.000)$ & $(0.000)$ \\
\hline \multirow[t]{2}{*}{ Pesaran (2004) CD LM } & 11.964 & 16.733 & 16.337 & 19.795 & 41.665 & 34.805 & 12.388 & 14.091 \\
\hline & $(0.000)$ & $(0.000)$ & $(0.000)$ & $(0.000)$ & $(0.000)$ & $(0.000)$ & $(0.000)$ & $(0.000)$ \\
\hline \multirow[t]{2}{*}{ Pesaran (2004) CD } & 5.667 & 6.364 & 6.163 & 6.896 & 10.233 & 9.370 & 5.219 & 5.446 \\
\hline & $(0.039)$ & $(0.000)$ & $(0.000)$ & $(0.000)$ & $(0.039)$ & $(0.000)$ & $(0.000)$ & $(0.000)$ \\
\hline \multirow[t]{2}{*}{ Bias-adjusted LM } & 7.074 & 9.238 & 18.672 & 19.498 & 41.103 & 42.719 & 11.853 & 11.812 \\
\hline & $(0.000)$ & $(0.000)$ & $(0.000)$ & $(0.000)$ & $(0.000)$ & $(0.000)$ & $(0.000)$ & $(0.000)$ \\
\hline
\end{tabular}

Not:() içindeki değerler olasılık (p) değerleridir.

Yatay kesit bağımlılığı test edildikten sonra eğim katsayılarının birimlere göre homojen olup olmadığı Pesaran ve Yamagata'nın (2008) çalışması takip edilerek test edilmiş ve sonuçlar Tablo 3'de paylaşılmıştır. Dört modelin her iki versiyonu içinde hesaplanan sonuçlara dikkat edildiğinde eğim parametrelerinin homojenliğini ifade eden $H_{0}$ hipotezinin 0.01 anlamlılık düzeyinde reddedildiği görülmektedir. Yani eğim parametreleri operatörlere göre farklılaşmaktadır. Bu sonuç operatörlerin kendilerine has yapılanmaları, piyasaya giriş zamanları ve zaman içinde yaşadıkları birleşme ve satılmalar dikkate alındığında beklentilerle uyumludur.

Tablo 3. Homojenlik Testi Sonuçları

\begin{tabular}{|c|c|c|c|c|c|c|c|c|c|}
\hline \multirow{2}{*}{ Testler } & & \multicolumn{2}{|l|}{ Model I } & \multicolumn{2}{|l|}{ Model II } & \multicolumn{2}{|c|}{ Model III } & \multicolumn{2}{|c|}{ Model IV } \\
\hline & & $a$ & $b$ & $a$ & $b$ & $a$ & $b$ & $a$ & $b$ \\
\hline \multirow[t]{2}{*}{$\widetilde{\Delta}$} & $t$-ist. & 24.345 & 24.743 & 5.504 & 4.284 & 5.698 & 5.717 & 7.437 & 7.148 \\
\hline & $p$-deg. & $(0.000)$ & $(0.000)$ & $(0.000)$ & $(0.000)$ & $(0.000)$ & $(0.000)$ & $(0.000)$ & $(0.000)$ \\
\hline \multirow[t]{2}{*}{$\widetilde{\Delta}_{a d j}$} & $t$-ist. & 25.534 & 25.951 & 5.773 & 4.493 & 5.917 & 5.936 & 7.724 & 7.424 \\
\hline & $p-$ & $(0.000)$ & $(0.000)$ & $(0.000)$ & $(0.000)$ & $(0.000)$ & $(0.000)$ & $(0.000)$ & $(0.000)$ \\
\hline
\end{tabular}

Yatay kesit bağımlılığı ve homojenliğin test edilmesinin ardından uzun dönemli ilişkinin varlığına bakmadan önce birim kök testi yapılarak serilerin durağanlığı araştırılmaktadır. Yatay kesitsel olarak değişken olan $n s$, mou ve rpm değişkenleri için CIPS testi (Pesaran, 2007) ve yatay kesitsel olarak değişken olmayan $h h i$, $c r l$ ve $g d p$ değişkenleri için ADF testi (1979) kullanılmış ve sonuçlar Tablo 4'de paylaşılmıştır. Elde edilen sonuçlara göre mou, rpm ve hhi değiş̧kenleri düzeyde durağandırlar. Düzeyde birim kök içerdikleri tespit edilen $n s, c r l$ ve $g d p$ değişkenlerinin ise birinci farkları alındığında durağan hale geldikleri belirlenmiştir. 
Kar, M. / Journal of Yasar University, 2020, 15/57, 72-83

Tablo 4. Birim Kök Test Sonuçları

\begin{tabular}{|c|c|c|c|c|c|}
\hline Testler & & Değişkenler & Test Ist. & Gecikme & Kri. De g. $(\% 1)$ \\
\hline \multirow{5}{*}{ CIPS } & \multirow{3}{*}{ Seviye } & $n s$ & -1.857 & 2 & -2.37 \\
\hline & & mou & -2.892 & 2 & -2.37 \\
\hline & & rpm & -3.873 & 2 & -2.37 \\
\hline & & & & & \\
\hline & Birinci Fark & $n s$ & -5.082 & 2 & -2.32 \\
\hline \multirow{6}{*}{$\mathrm{ADF}$} & & Değişkenler & Test İst. & Gecikme & 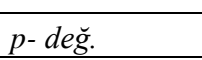 \\
\hline & \multirow{3}{*}{ Seviye } & hhi & 1.8227 & 2 & 0.0342 \\
\hline & & $\mathrm{crl}$ & -1.5033 & 2 & 0.9336 \\
\hline & & $g d p$ & -1.3894 & 2 & 0.9176 \\
\hline & \multirow[t]{2}{*}{ Birinci Fark } & crl & 8.8731 & 2 & 0.000 \\
\hline & & $g d p$ & 6.5843 & 2 & 0.000 \\
\hline
\end{tabular}

Katsayıların tahminine geçmeden önce son olarak eşbütünleşme testleri yapılarak seriler arasında durağan bir ilişkinin bulunup bulunmadığı her dört model içinde test edilmiş ve sonuçlar Tablo 5 'de paylaşılmıştır. Elde edilen $p$ değerleri incelendiğinde beklentilere uygun olarak hem gurup hem de panel istatistiği için 0.10 anlamlılık düzeylerinde $H_{0}$ hipotezinin reddedildiği ve değişkenler arasında uzun dönemli bir ilişkinin bulunduğu sonucuna ulaşılmaktadır.

Tablo 5. Eşbütünleşme Testi Sonuçları

\begin{tabular}{lllll}
\hline Testler & Model I & Model II & Model III & Model IV \\
\hline DH $_{g}$ Ístatistiği & $-1.521(0.064)$ & $-1.574(0.058)$ & $-1.541(0.062)$ & $-1.574(0.058)$ \\
$D H_{p} \dot{I}_{\text {statistiği }}$ & $-1.393(0.082)$ & $-1.490(0.068)$ & $-1.463(0.072)$ & $-1.483(0.069)$ \\
\hline
\end{tabular}

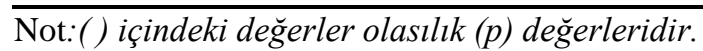

Uzun dönem eşbütünleşme katsayıları tahminine geçilmesi için gereken tüm adımlar tamamlanmış ve DCCE yöntemi yardımıyla her dört model farklı iki versiyonu ile tahmin edilmiş ve sekiz farklı tahmine ait sonuçlar Tablo 6'da paylaşılmıştır. Değişkenler ayrı ayrı ve modeller bir bütün halinde istatistiksel olarak anlamlı ve iktisadi beklentilerle uyumludur.

Tablo 6. Tahmin Sonuçları

\begin{tabular}{|c|c|c|c|c|c|c|c|c|}
\hline \multirow[b]{2}{*}{ Modeller } & \multicolumn{2}{|c|}{ Model I } & \multicolumn{2}{|c|}{ Model II } & \multicolumn{2}{|c|}{ Model III } & \multicolumn{2}{|c|}{ Model IV } \\
\hline & $a$ & $b$ & $a$ & $b$ & $a$ & $b$ & $a$ & $b$ \\
\hline $\begin{array}{c}\text { Bağımlı } \\
\text { Değiş. }\end{array}$ & $n s_{i t}$ & $n s_{i t}$ & $m^{\prime} u_{i t}$ & mou $_{i t}$ & $r p m_{i t}$ & rpm $_{i t}$ & $r p m_{i t}$ & $r p m_{i t}$ \\
\hline consit & $\begin{array}{l}1.211 \\
(0.00)\end{array}$ & $\begin{array}{l}1.722 \\
(0.00)\end{array}$ & $\begin{array}{l}1.619 \\
(0.00)\end{array}$ & $\begin{array}{l}1.603 \\
(0.00)\end{array}$ & $\begin{array}{l}2.251 \\
(0.00)\end{array}$ & $\begin{array}{l}2.291 \\
(0.00)\end{array}$ & $\begin{array}{l}1.427 \\
(0.00)\end{array}$ & $\begin{array}{l}1.423 \\
(0.00) \\
\end{array}$ \\
\hline$n s_{t-1}$ & $\begin{array}{l}0.304 \\
(0.00)\end{array}$ & $\begin{array}{l}0.341 \\
(0.00)\end{array}$ & - & - & $\begin{array}{c}1.99 \\
(0.00)\end{array}$ & $\begin{array}{c}2.08 \\
(0.00)\end{array}$ & - & - \\
\hline mout $t-1_{1}$ & - & - & $\begin{array}{l}0.705 \\
(0.00) \\
\end{array}$ & $\begin{array}{l}0.708 \\
(0.00) \\
\end{array}$ & - & - & $\begin{array}{l}1.179 \\
(0.00) \\
\end{array}$ & $\begin{array}{l}1.180 \\
(0.03 \\
\end{array}$ \\
\hline rpm $_{i t}$ & $\begin{array}{c}-0.058 \\
(0.00)\end{array}$ & $\begin{array}{l}-0.064 \\
(0.00) \\
\end{array}$ & $\begin{array}{l}-0.030 \\
(0.00) \\
\end{array}$ & $\begin{array}{l}-0.029 \\
(0.03)\end{array}$ & - & - & - & - \\
\hline$h h i_{i t-1}$ & $\begin{array}{l}0.196 \\
(0.00)\end{array}$ & - & $\begin{array}{l}0.156 \\
(0.00)\end{array}$ & - & $\begin{array}{l}2.802 \\
(0.00) \\
\end{array}$ & - & $\begin{array}{l}2.980 \\
(0.04) \\
\end{array}$ & - \\
\hline$c r 1_{i t-1}$ & - & $\begin{array}{l}0.722 \\
(0.00)\end{array}$ & - & $\begin{array}{l}0.675 \\
(0.01)\end{array}$ & - & $\begin{array}{l}2.598 \\
(0.01)\end{array}$ & - & $\begin{array}{l}2.546 \\
(0.05)\end{array}$ \\
\hline $\operatorname{gdp}_{\text {it }}$ & $\begin{array}{l}0.112 \\
(0.00)\end{array}$ & $\begin{array}{l}0.105 \\
(0.00)\end{array}$ & $\begin{array}{l}0.324 \\
(0.00)\end{array}$ & $\begin{array}{l}0.299 \\
(0.00)\end{array}$ & $\begin{array}{l}2.241 \\
(0.00)\end{array}$ & $\begin{array}{l}2.077 \\
(0.00)\end{array}$ & $\begin{array}{l}1.784 \\
(0.00)\end{array}$ & $\begin{array}{l}1.709 \\
(0.00)\end{array}$ \\
\hline
\end{tabular}

Not:() içindeki dĕgerler olasılık (p) değerleridir.

Ağa katılma ve ağı kullanma talebi için ağ dışsallıklarını analiz eden Model I ve Model II'ye bakıldığında ağ dışsallıklarının varlığını ve etki düzeyini gösteren iki değişken bağımlı değişkenin gecikmeli değeri ve piyasa yoğunlaşmasının gecikmeli değeridir. Her iki modelde de söz konusu değişkenlerin katsayılarının pozitif olarak elde edilmesi ağ dışsallıklarının varlığına işaret etmektedir. Geçmiş dönemdeki ağa katılma talebindeki \%1'lik bir artış ağ dışsallıklarının etkisi ile mevcut dönemdeki ağa katılma talebini her iki versiyona göre de yaklaşık \%0.3 artırmaktadır. Aynı şekilde geçmiş dönemdeki ağı kullanma talebinde meydana gelecek \%1'lik bir artış ağ dışsallıklarının etkisi ile mevcut dönemdeki ağı kullanma talebini her iki versiyona göre \%0.7 artırmaktadır. Geçmiş dönem piyasa yoğunlaşmasının mevcut dönem talep miktarına etkisini inceleyen katsayılar piyasanın rekabetçi yapıdan uzaklaşarak yoğunlaşmasının ağ dışsallıkları oluşturarak hem ağa katılma hem de ağı kullanma talebini artırdığı görülmektedir. 
Geçmiş dönemde ă̆ yoğunlaşmasında meydana gelecek \%1'lik bir değişiklik talep miktarını \%0.1 ile \%0.7 arasında artırmaktadır. Ayrıca fiyatta meydana gelecek \%1'lik bir artışın ağa katılma talebini yaklaşık \%0.05 azaltırken ağı kullanma talebinin \%0.03 azaltmaktadır. Gelirdeki \%1’lik artış ise ağa katılma talebini \%0.1 artırırken ağı kullanma talebini \%0.3 artırmaktadır.

Geçmiş dönem talep miktarından ve piyasa yoğunlaşmasından kaynaklı dışsallıkların piyasa fiyatını belirlemedeki rolünü ele alan Model III ve Model IV tahminlerinden elde edilen sonuçlar ağ dışsallıklarının firmaların fiyatı belirlerken

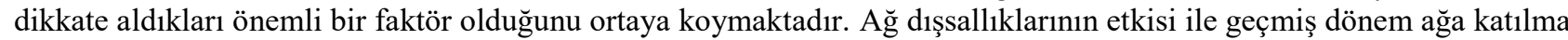
ve ağı kullanma talebi ile mevcut dönemdeki piyasa fiyatı arasındaki ilişki aynı yönlü olarak ortya çıkmaktadır. Geçmiş dönemdeki ağa katılma talebinde meydana gelecek \%1'lik bir artış piyasa fiyatını her iki versiyona göre de yaklaşık \%2 artırmaktadır. Ayrıca geçmiş dönemdeki ağı kullanma talebinde meydana gelecek \%1'lik bir artış piyasa fiyatını her iki tahmine göre de yaklaşık \%1.1 artırmaktadır. Tahmin sonuçlarına dikkat edildiğinde piyasa yoğunlaşmasını temsil eden değişkenlerde meydana gelecek \%1'lik bir artışın piyasa fiyatını \%2.5 ile \%3 arasında artıracağ1 görülmektedir. Ayrıca gelirde meydana gelecek bir artışın piyasa fiyatını \%1.7 ile \%2.2 arasında artıracağı elde edilen tahmin sonuçlarından hareketle söylenebilir.

\section{Sonuç}

Modern ekonomide ön plana çıkan ağ endüstrilerindeki tüketiciler faydanın büyük kısmını mal ya da hizmetlerin kendisinden değil ağ dışsallıklarının etkisi ile bu ürünleri çevreleyen ağlardan elde ederler. Tüketicinin fayda fonksiyonunda yer alarak bir mal ya da hizmete atfettiği değeri değiştiren ağ dışsallıkları gelinen noktada tüketici kararlarına ve firma stratejilerine yön vererek piyasayı şekillendiren önemli bir faktör olmuştur. Mobil telekomünikasyon piyasaları toplam abone sayısı ve aylık ortalama kullanım miktarı mevcut ve potansiyel tüketicilerin abone olma taleplerini, kullanım miktarını ve ödeme istekliliğini etkileyerek ağ dışsallıklarının görüldüğü önemli piyasa örneklerinden olmaktadır. Bu çalışmada Türkiye Mobil Telekomünikasyon Piyasası'ndaki ağ dışsallıklarının varlığı ve etkileri analiz edilmiştir. Ampirik analizde ikisi piyasa talebini ikisi de piyasa fiyatını dikkate alan dört farklı model Türkiye'deki mobil operatörlere ait 2005q1-2019q1 arasındaki çeyrek dönemlik panel veriler kullanılarak DCCE yöntemi aracılığıyla tahmin edilmiştir. Tahmin sonuçlarına göre Model I ve Model II'nin dört farklı versiyonunda da ağ dışsallıklarının varlığını ve etkisini gösteren katsayılar beklentilere uygun şekilde pozitif elde edilmiştir. Bunun anlamı geçmiş dönemdeki ağa katılım ve ağı kullanım talebinin büyümesi ve piyasanın yoğunlaşarak büyük ağlar oluşturmaș mevcut dönemdeki ağa katılım ve ağı kullanım talebini olumlu etkileyerek artırmaktadır. Yani mevcut ve potansiyel tüketiciler tüketim miktarları ve talep esnekliklerini belirlerken piyasanın geçmiş dönem telep mikatlarını ve operatörlerin pazar paylarını karar fonksiyonlarına belirleyici birer değişken olarak dahil etmektedirler. Model III ve Model IV tahminlerinden elde edilen sonuçlar firmaların fiyatı belirlerken ağ dişsallıklarını dikkate aldıkları ve tüketicilerin elde ettikleri faydanın bir kısmını fiyatları yüksek belirleyerek kendilerine transfer ettiklerini ortaya koymaktadır. Yani operatörler fiyatlama stratejilerini belirlerken ağ dışsallıklarının tüketicilerin talep esnekliklerine olan etkisini önemli bir faktör olarak kullanmakta ve mobil iletişim hizmeti için rekabetçi fiytaların üzerinde fiyatlar belirlemektedirler.

Elde edilen sonuçlar ağ dişsallıklarının ağ endüstrilerinde piyasa dinamiklerini şekillendiren bir faktör olarak önemini ortaya koymaktadır. A $\breve{g}$ dışsallıklarının göz ardı edilerek yapılacak piyasa analizlerinin eksik kalacağı aşikârdır. Mobil telekomünikasyon piyasalarındaki ağ dişsallıklarının önemli bir nedeni şebeke-içi/şebeke-dışı fiyat farklılıkları olduğundan çalışma dışsal olarak belirlenen arabağlantı ücretleri de modellere uygun şartlarda dahil edilerek zenginleştirilebilir. 


\section{KAYNAKÇA}

Ahuja, G. 2000. "Collaboration Networks, Structural Holes, And Innovation: A Longitudinal Study". Administrative Science Quarterly, 45 (3): 425-455.

Arthur, W. 1996. "Increasing Returns And The New World of Business". Harvard Business Review, 74(4): $100-109$.

Baltagi, B. H., Feng, Q. \& Kao, C. 2012. “A Lagrange Multiplier Test For Cross-Sectional Dependence In A Fixed Effects Panel Data Model”. Journal of Econometrics, 170:164-177.

Baraldi, A. L. 2012. "The Size Of The Critical Mass As A Function Of The Strength Of Network Externalities: A Mobile Telephone Estimation". Economics of Innovation and New Technology, 21(4), 373-396.

Birke, D., \& Swann, G. M. P. 2006. "Network Effects And The Choice Of Mobile Phone Operator". Journal of Evolutionary Economics, 16(1-2): 65-84.

Bonardi, J -P. \& Durand, R. 2003. "Managing Network Effects In High-Tech Markets”. Academy of Management Executive, 17 (4): 40-52.

Breusch, T. S. \& Pagan, A. 1980. "The Lagrange Multiplier Test And Its Applications To Model Specification In Econometrics". The Review of Economic Studies, 47(1): 239-253.

Brynjolfsson, E., \& Kemerer, C. 1996. "Network Externalities In Microcomputer Software: An Econometric Analysis Of The Spreadsheet Market". Management Science, 42: 1627-1647.

BTK, 2019a. https://www.btk.gov.tr/pazar-verileri (20.07.2019).

BTK, 2019b. Türkiye Elektronik Haberleşme Sektörü Pazar Verileri Raporu, https://www.btk.gov.tr/uploads/pages/pazar-verileri/2019-1-ceyrekraporu-kurumdisi-5d3579a08c809.pdf (20.07.2019).

Candogan, O., Bimpikis, K., \& Ozdaglar, A. 2012. "Optimal Pricing In Networks With Externalities”. Operations Research, 60(4): 883-905.

Chudik, A \& Pesaran, M.H. 2015. “Common Correlated Effects Estimation Of Heterogeneous Dynamic Panel Data Models With Weakly Exogenous Regressors". Journal of Econometrics, 188:393-420.

Church, J., Gandal, N., \& Krause, D. 2002. "Indirect Network Effects And Adoption Externalities". Foerder Institute for Economic Research. Working Paper 02-30.

Clements, M. 2004. "Direct And İndirect Network Effects Are They Equivalent?”. International Journal of Industrial Organization, 22: 633-645.

Dickey, D. A. \& Fuller, W. A. 1979. "Distribution Of The Estimators For Autoregressive Time Series With A Unit Root". Journal of the American Statistical Association, 74:427-431.

Doganoglu, T. \& Gryzbowski, L. 2007. "Estimating Network Effects in the Mobile Telephony in Germany". Information Economics and Policy, 19 (1): 65-79.

Economides N., \& Himmelberg C. 1995. "Critical Mass And Network Size With Application To The US Fax Market". Stern School of Business, New York University 'LVFXVVLRQ 3DSHU EC-95-11.

Fainmesser, I. P. \& Galeotti, A. 2016. "Pricing Network Effects: Competition". Johns Hopkins Carey Business School, Research Paper No. 17-08.

Farrell, J. \&Saloner, G. 1985. "Standardization, Compatibility, and Innovation”. RAND Journal of Economics, 16 (1): 70-83.

Farrell, J., \& Klemperer, P. 2007. "Co-Ordination And Lock-In: Competition With Switching Costs And Network Effects". in M. Armstrong and R. Porter (eds.) Handbook of Industrial Organization, Vol.3, Elsevier.

Frels, J.K., Shervani, T. \& Srivastava, R.K. 2003. "The Integrated Networks Model: Explaining Resource Allocations In Network Markets". Journal of Marketing, 67 (January): 29-45.

Fuentelsaz, L., Maicas, J.P. \& Polo, Y. 2010. "Switching Costs, Network Effects, and Competition in the European Mobile Telecommunications Industry". Information Systems Research, Forthcoming.

Gallaugher, J., \& Wang, Y. 2002. "Understanding Network Effects In Software Markets: Evidence From Web Server Pricing”. MIS Quarterly, 26: 303-327.

Gandal, N. 1995. "Competing Compatibility Standards And Network Externalities In The PC Software Market”. Review of Economics and Statistics, 77: 599-608.

Goolsbee, A. \& Klenow, P. 1999. "Evidence On Learning And Network Externalities In The Diffusion Of Home Computers." National Bureau of Economic Research, Working Paper \#7329.

Grajek M. 2002. "Identification of Network Externalities in Markets for NonDurables", Wissenschaftszentrum Berlin, Discussion Paper FS IV 02-32.

Grajek M. 2003. "Estimating Network Effects And Compatibility In Mobile Telecommunication”,. Wissenschaftszentrum Berlin, Discussion Paper SP II 2003-26.

Grajek, M. 2010. "Estimating Network Effects and Compatibility: Evidence from the Polish mobile market". Information Economics and Policy, 22(2): 130-143.

Jang, S.-L., Dai, S.-C. \& Sung, S. 2005. "The Pattern And Externality Effect Of Diffusion Of Mobile Telecommunications: The Case Of The OECD And Taiwan". Information Economics and Policy, 17: 133-148.

Kar, M . 2019. "Characteristics Of Mobile Communication Demand: The Case Of Turkey". Bolu Abant Izzet Baysal Üniversitesi Sosyal Bilimler Enstitüsü Dergisi, 19: 327-345 
Karaçuka, M. 2009. “Türk Mobil Telekomünikasyon Piyasalarında Firmaların Talep Özelliklerinin Belirleyicileri”. Dokuz Eylül Üniversitesi İktisadi ve İdari Bilimler Fakültesi Dergisi, 24(1): 1-13.

Katz, M. \& Shapiro, C. 1985. "Network Effect, Competition, and Compatibility". American Economic Review, 75: 424440.

Katz, M.L., \& Shapiro, C. 1994. "System Competition And Network Effects". Journal of Economic Perspectives, 8: 93 115.

Kim, H. S., \& Kwon, N. 2003. "The Advantage Of Network Size In Acquiring New Subscribers: A Conditional Logit Analysis Of The Korean Mobile Telephony Market". Information Economics and Policy, 15(1): 17-33.

Liebowitz, S. 2002. Re-Think The Network Economy: The True Forces That Drive The Digital Marketplace. New York: AMACOM.

Liebowitz, S.J., \& Margolis, S.E. 1994. "Network Externality: An Uncommon Tragedy". Journal of Economic Perspectives, 8: 133-150.

Maicas, J.P., Polo, Y. \& Sese, F.J. 2009a. "The Role Of (Personal) Network Effects And Switching Costs In Determining Mobile Users' Choice". Journal of Information Technology, 24 (2): 160-171.

Maicas, J.P., Polo, Y. \& Sese, F.J. 2009b. "Reducing the Level of Switching Costs in Mobile Communications: The Case of Mobile Number Portability”. Telecommunications Policy, 33 (9): 544-554.

McIntyre, D.P. \& Subramaniam, M. 2009. "Strategy in Network Industries: A Review and Research Agenda". Journal of Management, 35 (6): 1494-1517.

Ohashi, H. 2003. "The Role of Network Effects in the U.S. VCR Market, 1978-1986". Journal of Economics and Management Strategy, 12(4): 447-494.

Pesaran, H., Ullah, A. \& Yamagata, T. 2008. "A Bias- Adjusted LM Test Of Error Cross- Section Independence”. The Econometrics Journal, (11): 105-127.

Pesaran, H. 2004. "General Diagnostic Tests For Cross Section Dependence in Panels". University of Cambridge, Working Paper, CWPE 0435.

Pesaran, H. 2007. “A Simple Panel Unit Root Test In The Presence Of Cross-Section Dependence". Journal of Applied Econometrics, 22(2): 265-312.

Rohlfs, J. (1974). “A Theory Of İnterdependent Demand For A Communications Service”. Bell Journal of Economics, 5: $16-37$.

Schilling, M. A. 2002. "Technology Success and Failure in Winner-Take-All Markets: The Impact of Learning Orientation, Timing, and Network Externalities". The Academy of Management Journal, 45(2):387-398.

Shankar, V., \& Bayus, B. 2002. "Network Effects And Competition: An Empirical Analysis Of The Home Video Game Industry". Strategic Management Journal, 24: 375-384.

Shapiro, C., \& Varian, H.R. 1998. Information Rules - A Strategic Guide to the Network Economy. Harvard Business School Press, Boston.

Shew, W. 1994. "Regulation, Competition And Prices İn Cellular Telephony". The American Enterprise Institute for Public Policy Research, Working Paper no. 4329,

Sobolewski, M. \& Czajkowsi, M. 2012. "Network Effects And Preference Heterogeneity In The Case Of Mobile Telecommunications Markets". Telecommunications Policy, 36: 197-211.

Srinivasan, R., Lilien, G.L \& Rangaswamy, A. 2004. "First In, First Out? The Effects of Network Externalities on Pioneer Survival”. Journal of Marketing, 68 (January): 41- 58.

Suarez, F. 2005. "Network Effects Revisited: The Role Of Strong Ties In Technology Selection". Academy of Management Journal, 48: 710-722.

Swann, G.P. 2002. "The Functional Form of Network Effects". Information Economics and Policy, 14, 417-429.

Westerlund, J. 2008. "Panel Cointegration Tests of The Fisher Effect". Journal of Applied Econometrics, 23(2): 193-223. 